\title{
Cam-Clay モデルを用いた 2 層弾塑性体の分岐解析
}

\author{
Bifurcation Analysis in a Two-layer Cam-clay Model \\ 志比利秀* ・ 矢富盟祥 $* *$ \\ Toshihide SHIBI and Chikayoshi YATOMI
}

\begin{abstract}
*正会員 博工 島根大学助手 総合理工学部地球資源環境学科（T690-8504 松江市西川津町 1060）
**正会員 Ph.D. 金沢大学教授 工学部土木建設工学科（广920-8667 金沢市小立野二丁目 40-20）
\end{abstract}

\begin{abstract}
This paper examines the diffuse bifurcation mode of a two-layer specimen consisting of a non-coaxial Cam-clay model. The specimen undergoes a deformation by a prescribed velocity with no friction on the ends and a constant lateral hydrostatic pressure on the sides. We obtain several bifurcation loads and examine the effect of several material parameters on the bifurcation load. We finally investigate the sites where the slip planes first occur from the maximum shear strain point of view.
\end{abstract}

Key Words : bifurcation, two-layer, non-coaxial, Cam-clay model

\section{1.はじめに}

平面ひずみ状態を仮定した拡散分岐モードによる 分岐解析は，大きなスケールでは地層の褶曲，活断 層への遷移過程などの定性的かつ定量的な把握が期 待できる. 基本的な褶曲の形態にはたわみ (flexure) と押しつぶし (flattening, または thickening) の 2 つが考えられる．前者は，座屈や曲げにより各層が もとの厚さと層に沿う長さを保ったまま弓形，また は波型にたわむ場合を表しており，形態的には平行 褶曲となるものである。一方，後者は 1 方向からの

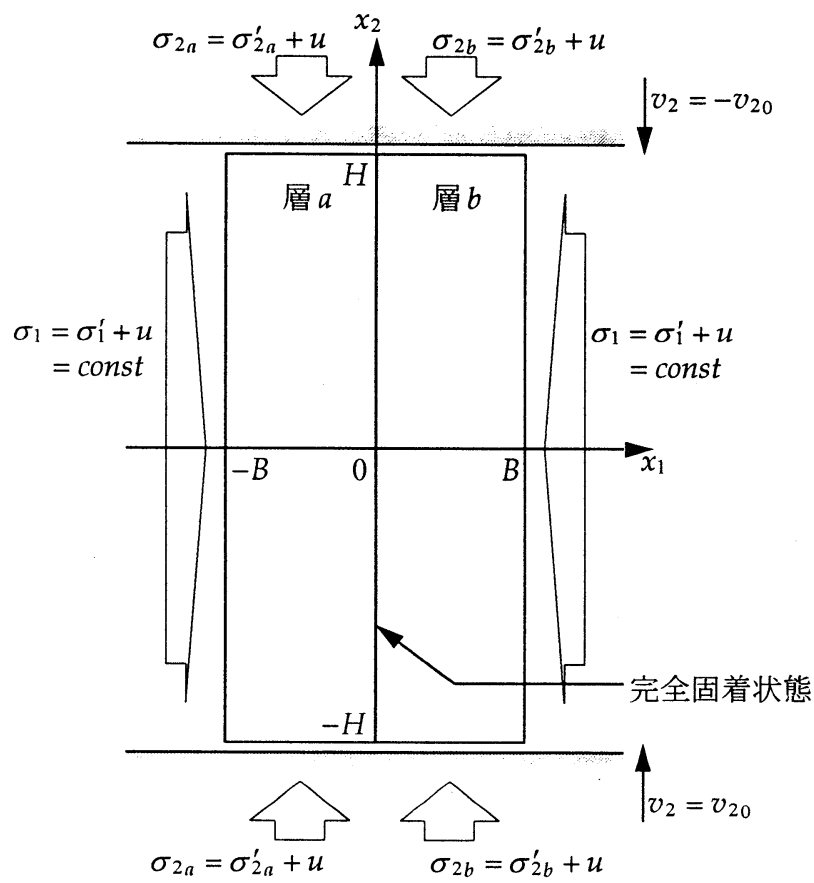

図-1 分岐直前の供試体概形図
圧縮に対して, 他の 2 方向もしくは 1 方向へ伸張す ることによって変形する場合である。このように， 拡散分岐モードによる分岐解析は, 座屈や押しつぶ しによる褶曲のメカニズムや地盤の不均一変形によ る破壊過程を考察するための重要な研究である.

現在までに論文されている弾塑性体の分岐解析で は，対象領域が一つの物質の場合のみである。しか し, 実際の地盤は異なる性質の物質が幾重にも積み 重なった多層体で構成されており，さらなる把握の ためには対象領域を多層と捉え, 物質間の相互干渉 の影響を考慮した解析が必要となる。なお, 弾性体 の場合は Biot ${ }^{1)}$ がいくつかの解析を行っている.

そこで, 本論文では基礎的研究として, 構成式に 有限変形非共軸 Cam-clay 弾塑性モデル2)を用いて, 厚さの等しい 2 層体を平面ひずみ状態のもとで圧縮 した場合の均一な変形から非均一な変形への分岐荷 重（詳細な定義は後述する）の解析解を誘導し, 分 岐モードと物質パラメータの関係や最大せん断ひず みの分布図より, 初期のすべり面（大きなスケール では断層面）の発生位置について考察を行った。

\section{2. 試験条件}

供試体は図-1 に示すように正規圧密された CamClay モデルの物質特性の異なる 2 つの層 $\mathrm{a}, \mathrm{b}$ からな るものとし, 供試体内の各点で非排水条件を満足す る平面ひずみ変形を考える，供試体の側面において は水圧一定とし, 上下端面においては, 変位制御で 圧縮し, 摩擦はないものとする。 また, 両層の界面 においては, 完全固着状態を考えている. 本論文で は, 両層が同一な均一変形状態から, 非均一変形状 
態への分岐現象を考えており，分岐の生じる瞬間 $t=t$ で, 図-1 のように各層がそれぞれ高さ $2 H$, 幅 $B$ になったものと考える. Cauchy 応力 $T_{i j}(i, j=1,2,3)$ 等は引張を正, 圧縮を負とするが，ギリシャ文字の 全応力 $\sigma_{i}(i=1,2,3)$, 間隙水圧 $u$, 体積ひずみ $v$ は土 質力学の慣例に従い圧縮を正とする.

まず, Cauchy 応力 $T$, 有効 Cauchy 応力 $T^{\prime}$ と間隙 水圧 $u$ の間に有効応力原理が次式で与えられる.

$$
T^{\prime}=T+u I
$$

ここで，I は単位テンソルである．また，前述した ように, 均一変形状態から非均一変形状態への分岐 を対象とするため, 分岐の生じる瞬間, 時刻 $t=t$ ま では両層とも同一な均一変形をしているが, 有効応 力および間隙水圧は各層で異なる均一な值となる. ゆえに, 時刻 $t=t$ での全応力は,

$$
\left(T_{i j}\right)=\left(\begin{array}{ccc}
-\sigma_{11}^{\prime} & 0 & 0 \\
0 & -\sigma_{i_{2}}^{\prime} & 0 \\
0 & 0 & -\sigma_{\mathrm{i}_{3}}^{\prime}
\end{array}\right)+\left(\begin{array}{ccc}
-u_{\mathrm{i}} & 0 & 0 \\
0 & -u_{\mathrm{i}} & 0 \\
0 & 0 & -u_{\mathrm{i}}
\end{array}\right)
$$

となる。以下，添字 $\mathrm{i}(\mathrm{i}=\mathrm{a}, \mathrm{b})$ は，それぞれは層 $\mathrm{a}$ ， 層 $\mathrm{b}$ の物理量および物質パラメータを表すものとす る.ただし, 各層を区別する添字 $\mathrm{i}(\mathrm{i}=\mathrm{a}, \mathrm{b})$ は, 記号 の煩雑化を避けるため, 自明の箇所は添字を省略す る.

また, $\sigma_{i_{3}}^{\prime}=\left(\sigma_{i_{2}}^{\prime}+\sigma_{1_{1}}^{\prime}\right) / 2$ と仮定すると, 平均有効 応力 $p_{i}^{\prime}$, 一般化された偏差応力 $q_{\mathrm{i}}$ は次のように定義 される。

$$
p_{\mathrm{i}}^{\prime}=-\frac{1}{3} \operatorname{tr} T_{\mathrm{i}}^{\prime}=\frac{\sigma_{\mathrm{i} 1}^{\prime}+\sigma_{\mathrm{i} 2}^{\prime}}{2}, \quad q_{\mathrm{i}}=\sqrt{\frac{3}{2} S_{\mathrm{i}} \cdot S_{\mathrm{i}}}=\frac{\sqrt{3}}{2}\left|\sigma_{\mathrm{i} 2}^{\prime}-\sigma_{\mathrm{i} 1}^{\prime}\right|
$$

ここに, $S$ は有効 Cauchy 応力 $T^{\prime}$ の偏差応力である.

なお，本論文では，分岐時における応力差 $q$ と平 均有効応力 $p^{\prime}$ の比 $q / p^{\prime}(=\eta)$ をもって「分岐荷重」と呼 ぶ. 粘土や砂質土においては, 平均有効応力が大き い程，せん断強度が大きいので，本論文のような均 一多軸状態における分岐荷重は軸応力 $\sigma_{2}$ や応力差 $\bar{q}=\left|\sigma_{2}^{\prime}-\sigma_{1}^{\prime}\right|$ ではなく, $q / p^{\prime}$ が物理的には最も合理的 な分岐荷重の定義であると考える.

\section{3. 有限変形 Cam-clay モデル}

等方圧密を考える. 間隙比を $e$ としてその微小増 分を $\dot{e}$ 表わすと, $\dot{e}$ は有効主応力増分との間に, $\dot{e}=-\lambda \dot{p}^{\prime} / p^{\prime}$ という関係が成り立つ. ゆえに，等方圧 密状態における体積ひずみ速度 $\dot{v}$ は,

$$
\dot{v}=\frac{\lambda}{1+e} \frac{\dot{p}^{\prime}}{p^{\prime}}
$$

となる.ここで， $\lambda$ は自然対数表示による圧縮指数 である. 同様に等方膨潤を考えると次式を得る.

$$
\dot{v}^{\mathrm{e}}=\frac{\kappa}{1+e} \frac{\dot{p}^{\prime}}{p^{\prime}}
$$

ここで， $\kappa$ は自然対数表示による膨潤指数である.

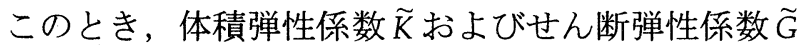
は，それぞれ次式で与えられる.

$$
\widetilde{K}=\widetilde{K}_{0} p^{\prime}, \quad \widetilde{G}=\widetilde{G}_{0} p^{\prime},
$$

ここで， $\widetilde{K}_{0}=\frac{1+e}{\kappa} ， \widetilde{G}_{0}=\frac{3(1-2 v)}{2(1+v)} \widetilde{K}_{0}$ とおいた.また, vはポアソン比である. 一方ダイレイタンシーによ る体積ひずみ速度は,

$$
\dot{v}^{\mathrm{p}}=D\left(\frac{q}{p^{\prime}}\right)
$$

となる.ここで，(..) は (...) の物質時間微分を表わ す.また，Dはダイレイタンシ一係数であり，限界 状態パラメータ $M^{3)}$ との間に次の関係,

$$
D=\frac{\lambda-\kappa}{M(1+e)}
$$

が成り立つ ${ }^{4)}$ 。結局, 塑性体積ひずみ速度は, 式(4), (5), (6)より次式となる.

$$
\dot{v}^{\mathrm{p}}=\frac{\lambda-\kappa}{1+e} \frac{\dot{p}^{\prime}}{p^{\prime}}+D\left(\frac{q}{p^{\prime}}\right)
$$

微小変形における Cam-clay モデル ${ }^{3)}$ を真似て降伏 汎関数を次のように与える.

$$
f=\int_{0}^{t}\left\{\frac{\lambda-\kappa}{1+e} \frac{\dot{p}^{\prime}}{p^{\prime}}+D\left(\frac{q}{p^{\prime}}\right)\right\} d t-v^{\mathrm{p}}
$$

ここで， $t=0$ のとき $v^{\mathrm{p}}=0$ とする. 一般に間隙比 $e$ は負荷にともない変化するが, 非排水状態を考えれ ば $e$ は時間 $t$ に関して一定となり, 式(7)の第 1 項は 簡単に積分できる.このとき, 有限変形共軸 Cam-clay モデル2）の構成式は次式で与えられる.

$$
\begin{aligned}
& \stackrel{\circ}{T_{i j}^{\prime}}=\left\{\left(\widetilde{K}-\frac{2}{3} \widetilde{G}\right) \delta_{i j} \delta_{k l}+\widetilde{G}\left(\delta_{i k} \delta_{j l}+\delta_{i l} \delta_{j k}\right)\right. \\
& \left.-\frac{1}{\widetilde{G}+\widetilde{h}}\left(\frac{\widetilde{G}}{\bar{\tau}} S_{i j}-\widetilde{K} \bar{\beta} \delta_{i j}\right)\left(\frac{\widetilde{G}}{\bar{\tau}} S_{k l}-\tilde{K} \bar{\beta} \delta_{k l}\right)\right\} D_{k l} \\
& \text { ここで, } \bar{\beta}=\beta / \sqrt{3}, \quad \bar{\tau}=\sqrt{S_{i j} S_{i j} / 2} \text { である. また }, T_{i j}^{\prime}
\end{aligned}
$$


は有効 Cauchy 応力の Jaumann rate で, $\dot{T}^{\prime}=\dot{T}^{\prime}-W T^{\prime}+T^{\prime} W$ で定義される. また， $D_{i j}$ は変形 速度， $W_{i j}$ はスピン， $\delta_{i j}$ は Kronecker の記号である. $\beta$ は限界パラメータ $M$ と応力比 $q / p^{\prime}$ を用いて,

$$
\beta=M-q / p^{\prime}
$$

で与えられる. $\widetilde{h}$ は,

$$
\widetilde{h}=\widetilde{K} \bar{\beta}^{2}+h
$$

であり， $h$ は硬化係数でダイレイタンシー係数 $D$ を 用いて,

$$
h=\frac{\bar{\beta}}{\sqrt{3} D} p^{\prime}
$$

で与えられる。

有限変形非共軸 Cam-clay モデルの構成式は， $h_{1}$ を 第 2 硬化係数とした時, 式(8)において物質パラメー 夕を次のように置き換えることによって与えられる.

$$
\begin{aligned}
& \widetilde{G} \rightarrow \frac{h_{1} \widetilde{G}}{h_{1}+\widetilde{G}} \\
& \widetilde{K} \rightarrow \frac{\left(h_{1}-h\right) \widetilde{K}}{h_{1}-h-\bar{\beta}^{2} \widetilde{K}} \\
& h \rightarrow \frac{h_{1} h}{h_{1}-h} \\
& \bar{\beta} \rightarrow \frac{h_{1} \bar{\beta}}{h_{1}-h}
\end{aligned}
$$

ただし，第 2 硬化係数 $h_{1}$ は式(9)の $h$ と同様の形で次 式のように仮定する.

$$
h_{1}=\frac{\bar{\beta}}{\sqrt{3} A} p^{\prime} \quad(>0)
$$

ここで，A を非共軸パラメータと呼び， $A=0$ で共 軸モデル， $A>0$ で非共軸モデルを表す.

現在まで，非共軸性を詳細に検討した定量的実験 は，ほとんど見られない.しかし，中空円柱ねじり 試験によるその存在, また, 存在の必要性を示した 研究は，最近精力的に行なわれている ${ }^{5)}$. なお，本 論文でも上記 $h_{1}$ は，参考文献 ${ }^{2)}$ の表現をそのまま 用いるが, 後述の 5,6 節で示す解析解には $h_{1}$ の具 体形は不要である.

また，各点非排水の条件は，

$$
\operatorname{tr}(D)=0
$$

となる．式(10)を考慮すると式(8)は次式となる.

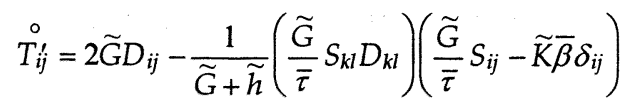

本論文では，平面ひずみ変形を仮定しているので 式(11), (10)は次のように変形できる.

$$
\begin{aligned}
& T_{11}^{\prime}-T_{22}^{\prime}=2 \mu^{*}\left(D_{11}-D_{22}\right) \\
& T_{12}^{\prime}=2 \mu D_{12} \\
& D_{11}+D_{22}=0 \\
& D_{33}=0
\end{aligned}
$$

ここで， $\mu^{*} ， \mu$ はそれぞれ 45 度せん断におけるせ ん断係数, 単純せん断係数で, 次式で与えられる.

$$
\mu^{*}=\frac{\widetilde{h} \widetilde{G}}{\widetilde{h}+\widetilde{G}}, \mu=\frac{h_{1} \widetilde{G}}{h_{1}+\widetilde{G}}
$$

なお， $\mu^{*}$ は非共軸パラメータ $A$ に無関係であり， $\mu$ は $A$ の単調減少関数となっている.

結局, 均一変形办ら分岐瞬間時の有限変形 Camclay モデルの構成関係は式(12), (14)で与えられる.

\section{2 層供試体における分岐荷重}

初期に等方圧密された 2 層供試体を軸方向に一定 速度で圧縮すると各層に働く軸圧に差が生じ，分岐 の生じる瞬間において各層の応力比 $\eta$ は異なってい る.

各層において式(3)の物質時間微分をとり， $T_{11}^{\prime}>T_{22}^{\prime}$ を仮定して式(11)，(13)を用いると次式が得 られる。

$$
\dot{p}^{\prime}=-\frac{\widetilde{G} \widetilde{K} \bar{\beta}}{\widetilde{G}+\widetilde{h}}\left(D_{11}-D_{22}\right), \quad \dot{q}=\sqrt{3} \frac{\widetilde{G} \tilde{h}}{\widetilde{G}+\widetilde{h}}\left(D_{11}-D_{22}\right)
$$

上式を用いると応力比 $\eta$ の物質時間微分は次式のよ うになる。

$$
\dot{\eta}=-\frac{\sqrt{3} \tilde{h}+\eta \widetilde{K} \bar{\beta}}{\widetilde{G}+\widetilde{h}} \widetilde{G}_{0}\left(D_{11}-D_{22}\right)
$$

$t=0$ において $q=0, p^{\prime}=p_{0}^{\prime}$ を考慮にいれ， $t=0$ から， $t=t$ まで上式を積分すると

$$
\begin{aligned}
& \int_{0}^{t}\left(D_{11}-D_{22}\right) d t= \\
& \frac{\sqrt{3}}{\left(1+D M \widetilde{K}_{0}\right) G_{0}}\left\{D \widetilde{G}_{0} \ln \frac{M-\eta}{M}-\frac{\eta}{3}+\frac{D \widetilde{K}_{0}}{6}\left(\eta^{2}-2 M \eta\right)\right\}
\end{aligned}
$$


となる. 分岐の瞬間まで両層は同じ均一変形を続け ているので, その間, 前式左辺は両層で同一な值と なる. したがって前式右辺を $g(\eta)$ とおくと, 各層の 応力比 $\eta$ は次の条件を満足する必要がある.

$$
[g(\eta)]=0
$$

ここで, 以後 $[. .$.$] は層 \mathrm{a}, \mathrm{b}$ における ... の差を表わす なお，式(15)の条件式は，非共軸パラメータ $A$ に無 関係であることに注意する。

層幅の等しい二層供試体全体としての分岐荷重を 本論文では次式で定義する(Appendix).

$$
\frac{q}{p^{\prime}}=\frac{q_{\mathrm{a}}+q_{\mathrm{b}}}{p_{\mathrm{a}}^{\prime}+p_{\mathrm{b}}^{\prime}}
$$

ここで, 各層の $p^{\prime}, q$ は各層の $\eta$ より次のようにし て求める. 常に負荷を加えながら非排水状態にある ことを考えると式(4)，(6)より，体積ひずみ速度は 零であるから，

$$
\dot{v}=\frac{\lambda}{1+e} \frac{\dot{p}^{\prime}}{p^{\prime}}+D\left(\frac{q}{p^{\prime}}\right)=0
$$

であり, $t=0$ において $q=0, p^{\prime}=p_{0}^{\prime}$ を考慮にいれ， $t=0$ から $\quad t=t$ まで上式を積分すると

$$
p^{\prime}=p_{0}^{\prime} \exp \left(-\frac{1+e}{\lambda} D \eta\right)
$$

となり $q=\eta p^{\prime}$ であることより，

$$
q=\eta p_{0}^{\prime} \exp \left(-\frac{1+e}{\lambda} D \eta\right)
$$

で与えられる.

\section{5. 支配方程式}

前述したように, 異なる 2 つの層からなる長方形 供試体は, 分岐の生じる直前まで, 軸方向変形の増 大に対して均一に変形したとする. そのとき，次の 軸方向変形の増大においても, 均一変形は可能な解 の一つである. ゆえに, 分岐は, 次の軸方向変形の 增大において均一変形とは異なった解，つまり，非 均一な変形を示す解が存在するときに生じると考え る.

なお，分岐が実際に生じるためには，その時の均 一解が不安定となる必要がある. 弾性体では, 解の 唯一性がなくなる時, その均一解は不安定となるが, 弾塑性体では, その場合でも均一解が依然安定であ ることもある ${ }^{6)}$ ．すなわち，弾塑性体の場合，この 安定性を吟味するためには, 負荷, 除荷領域を考慮
したあらゆる仮想速度場を想定した増分解が必要と なる. 梁構造などのように, 変形が比較的単純な場 合は，そのような安定性を吟味することは可能であ るが，本論文のような連続体の場合，仮想速度場を 特殊なものに限定せず，除荷領域を含めた一般的な 仮想速度場を想定した場合の安定性の吟味は非常に 難しく, 著者らの知る限り, それに関する論文は皆 無である.

したがって, 本論文での分岐解も, その分岐解へ 移行する可能性の範囲内での議論である. しかしな がら, 現実の物質では, 注意深く均一な供試体を作 成しても，何らかの初期不整（試験機，偏心荷重や 両端摩擦などの不整を含む）が存在するから，均一 変形は, 不安定的であり, 初期不整の性質にもよる が，通常，最小分岐荷重で分岐すると考えることが できる ${ }^{6)}$ 。

\section{1 増分釣合式}

準静的で物体力のない場合を考えると，増分釣合 式は次式のようになる.

$$
\operatorname{div} \dot{S}_{t}=o
$$

ここで， $\dot{S}_{t}$ は全公称応力速度であり, Cauchy 応力 $T$, 速度勾配 $L$, 変形速度 $D$ を用いて次式で定義さ れる。

$$
\dot{S}_{t}=\dot{T}+T(\operatorname{tr} D)-T L^{T}
$$

ここで，上式に式(1)の有効応力原理と, 各点非排水 の条件，式(10)を用いると，

$$
\dot{S}_{t}=\dot{T}^{\prime}-T^{\prime} L^{T}-\dot{u} I+u L^{T}
$$

となる. 増分釣合式は上式を, $\operatorname{div} \mathbf{L}^{T}=\operatorname{grad}(\operatorname{tr} \boldsymbol{D})=\boldsymbol{0}$, また有効応力が分岐の瞬間まで均一であることを考 慮して, 式(17)に代入すると次式となる。

$$
\operatorname{div} \dot{T}^{\prime}-\operatorname{grad} \dot{u}=0
$$

結局, 平面ひずみ変形を考慮に入れると, 指標表示 を用いて，増分釣合式(18)は，次式のように表せる.

$$
\left.\begin{array}{l}
\dot{T}_{11,1}^{\prime}+\dot{T}_{12,2}^{\prime}-\dot{u}_{1,1}=0, \\
\dot{T}_{21,1}^{\prime}+\dot{T}_{22,2}^{\prime}-\dot{u}_{, 2}=0 .
\end{array}\right\}
$$

\section{2 境界条件}

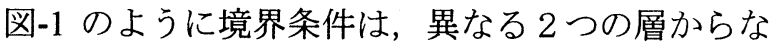
る長方形供試体の側面 $\left(x_{1}= \pm B\right)$ では側方水圧一定条 件とし, 上下端部 $\left(x_{2}= \pm H\right)$ では, 摩擦なしで, かつ 
一定速度 $v_{20}(>0)$ による変位制御圧縮とする. また, 界面 $\left(x_{1}=0\right)$ では完全固着状態，したがって速度が連 続であり，かつ力の釣合い条件より全公称表面力速 度の連続性が要求される．以上より境界条件は次式 で与えられる

$\left(\dot{s}_{t}\right)_{1}=\sigma_{1} L_{11},\left(\dot{s}_{t}\right)_{2}=\sigma_{1} L_{12}$, on $x_{1}= \pm B$,

$\left(\dot{s}_{t}\right)_{1}=0, v_{2}=\mp v_{20}$, on $x_{2}= \pm H$,

$\left[\left(\dot{s}_{t}\right)_{1}\right]=0,\left[\left(\dot{s}_{t}\right)_{2}\right]=0,\left[v_{1}\right]=0,\left[v_{2}\right]=0$, on $x_{1}=0$.

となる. ここで, $\dot{\boldsymbol{s}}_{t}\left(\left(\dot{s}_{t}\right)_{i}, i=1,2\right)$ は全公称表面力速度 であり, 全公称応力速度 $\dot{S}_{t}$, 各々の面の単位法線べ クトル $\boldsymbol{n}$ を用いて次式で定義される.

$$
\dot{\boldsymbol{s}}_{t}=\dot{S}_{t} n
$$

構成式(11)を増分釣合式(18)に代入したものは，速 度勾配に関して線形になっているので, 供試体の変 形を均一変形と非均一変形から構成されるものと考 え, 増分境界值問題の解は次のように, 均一境界条 件（各点で均一な解となる境界条件）と非均一境界 条件（非均一な解が得られる境界条件）の解の和と なる。

a) 均一境界条件

$\dot{T}_{11}^{\prime}=0, \dot{T}_{21}^{\prime}=0$, on $x_{1}= \pm B$, $\dot{T}_{12}^{\prime}=0, v_{2}=\mp v_{20}$, on $x_{2}= \pm H$, $\left[\dot{T}_{11}^{\prime}\right]=0,\left[\dot{T}_{21}^{\prime}\right]=0,\left[v_{1}\right]=0,\left[v_{2}\right]=0$, on $x_{1}=0$.

b) 非均一境界条件（境界条件）

$\dot{T}_{11}^{\prime}=\dot{u}_{\mathrm{a}}, \dot{T}_{21}^{\prime}=-\bar{q}_{\mathrm{a}} L_{12}$, on $x_{1}=-B$,

$\dot{T}_{11}^{\prime}=\dot{u}_{\mathrm{b}}, \dot{T}_{21}^{\prime}=-\bar{q}_{\mathrm{b}} L_{12}$, on $x_{1}=+B$,

$\dot{T}_{12}^{\prime}=0, v_{2}=0$, on $x_{2}= \pm H$,

$\left[\dot{T}_{11}^{\prime}\right]=[\dot{u}],\left[\dot{T}_{21}^{\prime}\right]=-\left[\bar{q} L_{12}\right],\left[v_{1}\right]=0,\left[v_{2}\right]=0$, on $x_{1}=0$.

このとき, 均一な変形 $\left(D_{11}=-D_{22}=v_{20} / H\right.$, $\left.D_{12}=W_{12}=0\right)$ は増分釣合式, 境界条件を自動的に満 足するため, 求めるべき分岐条件式は増分釣合式(19) 之非均一変形に寄与寸る境界条件式(22)より求めら れる. 以下, 非均一境界条件式(22)をもって境界条 件と呼ぶ.

\section{6. 特性方程式による支配方程式の分類}

各層において式(13)を満足するように流れ関数 $\psi_{\mathrm{i}}$ $(\mathrm{i}=\mathrm{a}, \mathrm{b})$ を用いて速度場を次のように与える.

$$
v_{\mathrm{i} 1}=\psi_{\mathrm{i}, 2}, v_{\mathrm{i} 2}=-\psi_{\mathrm{i}, 1}
$$

このとき，式(12)で表わされる構成式は流れ関数 $\psi_{\mathrm{i}}$ $(\mathrm{i}=\mathrm{a}, \mathrm{b})$ を用いると, 各層において，

$$
\begin{gathered}
\dot{\mathrm{T}}_{\mathrm{i}_{11}}^{\prime}-\dot{\mathrm{T}}_{\mathrm{i} 22}^{\prime}=4 \mu_{\mu_{i}}^{*} \psi_{\mathrm{i}, 12} \\
2 \dot{\mathrm{T}}_{\mathrm{i} 12}^{\prime}=\left(2 \mu_{\mathrm{i}}-\bar{q}_{\mathrm{i}}\right) \psi_{\mathrm{i}, 22}-\left(2 \mu_{\mathrm{i}}+\bar{q}_{\mathrm{i}}\right) \psi_{\mathrm{i}, 11}
\end{gathered}
$$

となる.また，式(19)の増分釣合式から $\dot{u}$ の項を消 去して式(24)を用いると，流れ関数を用いた増分釣 合式は次式のように得られる.

$$
a_{\mathrm{i}} \psi_{\mathrm{i}, 1111}-2 b_{\mathrm{i}} \psi_{\mathrm{i}, 1122}+c_{\mathrm{i}} \psi_{\mathrm{i}, 2222}=0
$$

ここで $a_{\mathrm{i}}, b_{\mathrm{i}}$, および $c_{\mathrm{i}}$ は次式である.

$$
a_{\mathrm{i}}=2 \mu_{\mathrm{i}}+\bar{q}_{\mathrm{i}}, b_{\mathrm{i}}=-\left(4 \mu_{\mathrm{i}}^{*}-2 \mu_{\mathrm{i}}\right), c_{\mathrm{i}}=2 \mu_{\mathrm{i}}-\bar{q}_{\mathrm{i}}
$$

また，流れ関数を用いた境界条件は次式となる.

$$
\begin{array}{ll}
a_{\mathrm{a}} \psi_{\mathrm{a}, 111}-\left(2 b_{\mathrm{a}}-a_{\mathrm{a}}\right) \psi_{\mathrm{a}, 122}=0 & \text { on } x_{1}=-B, \\
a_{\mathrm{b}} \psi_{\mathrm{b}, 111}-\left(2 b_{\mathrm{b}}-a_{\mathrm{b}}\right) \psi_{\mathrm{b}, 122}=0 & \text { on } x_{1}=+B, \\
\psi_{\mathrm{a}, 11}-\psi_{\mathrm{a}, 22}=0,\left(a_{\mathrm{a}} \neq 0\right) & \text { on } x_{1}=-B, \\
\psi_{\mathrm{b}, 11}-\psi_{\mathrm{b}, 22}=0,\left(a_{\mathrm{b}} \neq 0\right) & \text { on } x_{1}=+B, \\
\psi_{\mathrm{i}, 1}=0 \quad(\mathrm{i}=\mathrm{a}, \mathrm{b}) & \text { on } x_{2}= \pm H, \\
\psi_{\mathrm{i}, 22}=0,\left(c_{\mathrm{i}} \neq 0\right) \quad(\mathrm{i}=\mathrm{a}, \mathrm{b}) & \text { on } x_{2}= \pm H, \\
{\left[a \psi_{, 111}-(2 b-a) \psi_{, 122}\right]=0} & \text { on } x_{1}=0, \\
{\left[\psi_{, 11}-\psi_{, 22}\right]=0,(a \neq 0)} & \text { on } x_{1}=0, \\
{\left[\psi_{, 2}\right]=0} & \text { on } x_{1}=0, \\
{\left[\psi_{, 1}\right]=0} & \text { on } x_{1}=0 .
\end{array}
$$

上下端 $\left(x_{2}= \pm H\right)$ の境界条件から, 流れ関数 $\psi_{\mathrm{i}}$ を次 のようにおく.

$$
\psi_{\mathrm{i}}=V_{\mathrm{i}}\left(x_{1}\right) \cos \left(k_{m} x_{2}\right)
$$

ここで, $\quad k_{m}=m \pi / 2 H, \quad m=0,1,2, \ldots$ である.ただし， 変形モードを示す整数 $m$ が偶数のとき, 上下面の境 界条件を満足するために $x_{2}$ 座標の原点を $H / m$ だけ 移動させる必要がある。 また, $V_{\mathrm{i}}\left(x_{1}\right)$ は未知関数で ある. 式(25)に式(28)を用いると，各層の $V_{\mathrm{i}}\left(x_{1}\right)$ 支配 方程式は次式のようになる。

$$
\left(a_{\mathrm{i}} \mathrm{D}^{4}+2 b_{\mathrm{i}} k_{m}^{2} \mathrm{D}^{2}+c_{\mathrm{i}} k_{m}^{4}\right) V_{\mathrm{i}}\left(x_{1}\right)=0,
$$

ここで， $\mathrm{D}^{k}$ は $x_{1}$ に関する微分演算子であり， $k$ は その微分の回数を表わしている. 式(27)に式(28)を 用いると側面の境界条件は,

$$
\begin{array}{ll}
a_{\mathrm{a}} V_{\mathrm{a}, 111}+\left(2 b_{\mathrm{a}}-a_{\mathrm{a}}\right) k_{m}^{2} V_{\mathrm{a}, 1}=0 & \text { on } x_{1}=-B, \\
a_{\mathrm{b}} V_{\mathrm{b}, 111}+\left(2 b_{\mathrm{b}}-a_{\mathrm{b}}\right) k_{m}^{2} V_{\mathrm{b}, 1}=0 & \text { on } x_{1}=+B, \\
V_{\mathrm{a}, 11}+k_{m}^{2} V_{\mathrm{a}}=0,\left(a_{\mathrm{a}} \neq 0\right) & \text { on } x_{1}=-B, \\
V_{\mathrm{b}, 11}+k_{m}^{2} V_{\mathrm{b}}=0,\left(a_{\mathrm{b}} \neq 0\right) & \text { on } x_{1}=+B,
\end{array}
$$


となり，界面の境界条件は次のようになる．

$$
\begin{array}{ll}
{\left[a V_{, 111}+(2 b-a) k_{l l}^{2} V_{, 1}\right]=0} & \text { on } x_{1}=0, \\
{\left[V_{11}+k_{l l 1}^{2} V\right]=0,\left(a_{\mathrm{i}} \neq 0\right)} & \text { on } x_{1}=0, \\
{[V]=0} & \text { on } x_{1}=0, \\
{\left[V_{, 1}\right]=0} & \text { on } x_{1}=0 .
\end{array}
$$

また，支配方程式(29)は次のように変形できる.

$$
\left(\mathrm{D}^{2}+k_{m}^{2} \rho_{\mathrm{i}}^{2}\right)\left(\mathrm{D}^{2}+k_{m}^{2} \bar{\rho}_{\mathrm{i}}^{2}\right) V\left(x_{1}\right)=0,
$$

ここで， $\rho_{\mathrm{i}}, \quad \bar{\rho}_{\mathrm{i}}$ は次式で与えられる.

$$
\rho_{\mathrm{i}}^{2}, \bar{\rho}_{\mathrm{i}}^{2}=\frac{b_{\mathrm{i}} \pm \sqrt{b_{\mathrm{i}}^{2}-a_{\mathrm{i}} c_{\mathrm{i}}}}{a_{\mathrm{i}}}
$$

これは次式のような 4 次方程式の根である.

$$
a_{\mathrm{i}} \rho_{\mathrm{i}}^{4}-2 b_{\mathrm{i}} \rho_{\mathrm{i}}^{2}+c_{\mathrm{i}}=0
$$

ここで $a_{\mathrm{i}}, b_{\mathrm{i}}$, および $c_{\mathrm{i}}$ は式(26)と同様である.

$a_{\mathrm{i}}, b_{\mathrm{i}}$ ，および $c_{\mathrm{i}}$ は応力の関数であり，ゆえに供 試体内の応力状態の変化にともない式(34)の実数解 の存在個数が異なり, 実数解の存在個数が 0,2 お よび 4 個に対応して支配方程式(25)はそれぞれ楕円 型 $(\mathrm{E})$, 放物型 $(\mathrm{P})$ および双曲型 $(\mathrm{H})$ に分類される. $\mathrm{E}$ 領域は解の形により更に 2 つの領域に分類でき 4 つ の複素数解の場合を(EC)領域, 4 つの虚数解の場合 を(EI)領域と分類する. なお，それぞれの領域の判 別条件は次式で与えられる.

$$
\begin{array}{ll}
b_{\mathrm{i}}^{2}-a_{\mathrm{i}} c_{\mathrm{i}}>0, b_{\mathrm{i}} / a_{\mathrm{i}}<0,2 \mu_{\mathrm{i}}>\left|\bar{q}_{\mathrm{i}}\right| & \mathrm{EI} \text { 領域 } \\
b_{\mathrm{i}}^{2}-a_{\mathrm{i}} c_{\mathrm{i}}<0 & \mathrm{EC} \text { 領域 } \\
b_{\mathrm{i}}^{2}-a_{\mathrm{i}} c_{\mathrm{i}}>0, b_{\mathrm{i}} / a_{\mathrm{i}}>0,2 \mu_{\mathrm{i}}>\left|\bar{q}_{\mathrm{i}}\right| & \mathrm{H} \text { 領域 } \\
2 \mu_{\mathrm{i}}<\left|\bar{q}_{\mathrm{i}}\right| & \mathrm{P} \text { 領域 }
\end{array}
$$

また，支配方程式の分類に基づき，式(32)から $V_{\mathrm{i}}\left(x_{1}\right)$ の一般解は次式のようになる.

$$
V_{\mathrm{i}}\left(x_{1}\right)=\sum_{j=1}^{4} c_{\mathrm{i} j} \exp \left(i \rho_{\mathrm{i} j} x_{1}\right)
$$

ここで, $\quad c_{i j}(j=1,2, \ldots, 4)$ は未定定数である.

\section{6. 分岐条件式}

分岐条件式は側面 $\left(x_{1}= \pm B\right)$ および界面 $\left(x_{1}=0\right)$ の境 界条件式において， $c_{i j}(\mathrm{i}=\mathrm{a}, \mathrm{b})(j=1,2, \ldots, 4)$ の非自明な 解が存在する条件として得られる. なお, 最小の分 岐荷重はほとんどの場合 EC 領域で生じるので, 本 論文では EC 領域のみを考察した。

\section{$\mathrm{EC}$ 領域の分岐条件式}

式(34)で与えられる $4 つ の$ 複素数解 $\rho, \bar{\rho}$ は共役な 複素数であり, $\rho_{\mathrm{i}}, \bar{\rho}_{\mathrm{i}}=P_{1} \pm i Q_{\mathrm{i}}\left(P_{1}>0, Q_{\mathrm{i}}>0\right)$ とおく と $P_{\mathrm{i}}$ と $Q_{\mathrm{i}}$ の間には次の関係式が得られる.

$$
P_{\mathrm{i}^{2}}^{2}+Q_{\mathrm{i}}^{2}=\sqrt{c_{\mathrm{i}} / a_{\mathrm{i}}}, P_{\mathrm{i}}^{2}-Q_{\mathrm{i}}^{2}=b_{\mathrm{i}} / a_{\mathrm{i}}
$$

また，式(35)の $V_{\mathrm{i}}\left(x_{1}\right)$ は次式のようになる.

$$
\begin{aligned}
& V_{\mathrm{a}}\left(x_{1}\right)=\mathfrak{R}\left[C_{1} \sin \left(\rho_{\mathrm{a}} k_{m} x_{1}\right)+C_{2} \cos \left(\rho_{\mathrm{a}} k_{m} x_{1}\right)\right] \\
& V_{\mathrm{b}}\left(x_{1}\right)=\mathfrak{R}\left[C_{3} \sin \left(\rho_{\mathrm{b}} k_{m} x_{1}\right)+C_{4} \cos \left(\rho_{\mathrm{b}} k_{m} x_{1}\right)\right]
\end{aligned}
$$

ここで， R[...] で [...]の実数部分を表わす．また， $C_{i}(i=1, \ldots, 4)$ は複素数であり，それぞれ，

$$
\begin{array}{ll}
C_{1}=\chi_{1}+i \chi_{2}, & C_{2}=\chi_{3}+i \chi_{4}, \\
C_{3}=\chi_{5}+i \chi_{6}, & C_{4}=\chi_{7}+i \chi_{8} .
\end{array}
$$

と表わす.

側面 $\left(x_{1}= \pm B\right)$ の境界条件式(30)および界面 $\left(x_{1}=0\right)$ の境界条件式(31)に速度場の一般解，つまり式(37) を代入することにより次式を得る。

$$
\begin{array}{r}
A_{11} \chi_{1}+A_{12} \chi_{2}+A_{13} \chi_{3}+A_{14} \chi_{4}=0 \\
A_{25} \chi_{5}+A_{26} \chi_{6}+A_{27} \chi_{7}+A_{28} \chi_{8}=0 \\
A_{31} \chi_{1}+A_{32} \chi_{2}+A_{33} \chi_{3}+A_{34} \chi_{4}=0 \\
A_{45} \chi_{5}+A_{46} \chi_{6}+A_{47} \chi_{7}+A_{48} \chi_{8}=0 \\
A_{51} \chi_{1}+A_{52} \chi_{2}+A_{55} \chi_{5}+A_{56} \chi_{6}=0 \\
A_{63} \chi_{3}+A_{64} \chi_{4}+A_{67} \chi_{7}+A_{68} \chi_{8}=0 \\
A_{73} \chi_{3}+A_{77} \chi_{7}=0 \\
A_{81} \chi_{1}+A_{82} \chi_{2}+A_{85} \chi_{5}+A_{86} \chi_{6}=0
\end{array}
$$

ただし，式（38）の係数は，以下の通りである.

$A_{11}=\left\{\xi P \cos \left(P k_{m} B\right) \cosh \left(Q k_{m} B\right)+\varsigma Q \sin \left(P k_{m} B\right) \sinh \left(Q k_{m} B\right)\right\}_{\mathrm{a}}$ $A_{12}=\left\{\xi P \sin \left(P k_{m} B\right) \sinh \left(Q k_{m} B\right)-\varsigma Q \cos \left(P k_{m} B\right) \cosh \left(Q k_{m} B\right)\right\}_{\mathrm{a}}$ $A_{13}=\left\{\xi P \sin \left(P k_{m} B\right) \cosh \left(Q k_{m} B\right)-\varsigma Q \cos \left(P k_{m} B\right) \sinh \left(Q k_{m} B\right)\right\}_{\mathrm{a}}$ $A_{14}=\left\{-\xi P \cos \left(P k_{m} B\right) \sinh \left(Q k_{m} B\right)-\varsigma Q \sin \left(P k_{m} B\right) \cosh \left(Q k_{m} B\right)\right\}_{\mathrm{a}}$ $A_{25}=\left\{\xi P \cos \left(P k_{m} B\right) \cosh \left(Q k_{m} B\right)+\varsigma Q \sin \left(P k_{m} B\right) \sinh \left(Q k_{m} B\right)\right\}_{b}$ $A_{26}=\left\{\xi P \sin \left(P k_{m} B\right) \sinh \left(Q k_{m} B\right)-\varsigma Q \cos \left(P k_{m} B\right) \cosh \left(Q k_{m} B\right)\right\}_{b}$ $A_{27}=\left\{-\xi P \sin \left(P k_{m} B\right) \cosh \left(Q k_{m} B\right)+\varsigma Q \cos \left(P k_{m} B\right) \sinh \left(Q k_{m} B\right)\right\}_{\mathrm{b}}$ $A_{28}=\left\{\xi P \cos \left(P k_{m} B\right) \sinh \left(Q k_{m} B\right)+\varsigma Q \sin \left(P k_{m} B\right) \cosh \left(Q k_{m} B\right)\right\}_{\mathrm{b}}$ $A_{31}=\left\{-(a-b) \sin \left(P k_{m} B\right) \cosh \left(Q k_{m} B\right)\right.$

$A_{32}=\left\{(a-b) \cos \left(P k_{m} B\right) \sinh \left(Q k_{m} B\right)\right.$

$$
\left.-\sqrt{a c-b^{2}} \cos \left(P k_{m} B\right) \sinh \left(Q k_{m} B\right)\right\}_{a}
$$
$\left.-\sqrt{a c-b^{2}} \sin \left(P k_{m} B\right) \cosh \left(Q k_{m} B\right)\right\}_{a}$

$A_{33}=\left\{(a-b) \cos \left(P k_{m} B\right) \cosh \left(Q k_{m} B\right)\right.$

$$
-\sqrt{a c-b^{2}} \sin \left(P k_{m} B\right) \sinh \left(\left(k_{m} B\right)\right\}_{a}
$$

$A_{34}=\left\{(a-b) \sin \left(P k_{m} B\right) \sinh \left(Q k_{m} B\right)\right.$

$$
\left.+\sqrt{a c-b^{2}} \cos \left(P k_{m} B\right) \cosh \left(Q k_{m} B\right)\right\}_{\mathrm{a}}
$$


$A_{45}=\left\{(a-b) \sin \left(P k_{m} B\right) \cosh \left(Q k_{m} B\right)\right.$

$\left.+\sqrt{a c-b^{2}} \cos \left(P k_{m} B\right) \sinh \left(Q k_{m} B\right)\right\}_{\mathrm{b}}$

$A_{46}=\left\{-(a-b) \cos \left(P k_{m} B\right) \sinh \left(Q k_{m} B\right)\right.$ $\left.+\sqrt{a c-b^{2}} \sin \left(P k_{m} B\right) \cosh \left(Q k_{m} B\right)\right\}_{\mathrm{b}}$

$A_{47}=\left\{(a-b) \cos \left(P k_{m} B\right) \cosh \left(Q k_{m} B\right)\right.$ $\left.-\sqrt{a c-b^{2}} \sin \left(P k_{m} B\right) \sinh \left(Q k_{m} B\right)\right\}_{\mathrm{b}}$

$A_{48}=\left\{(a-b) \sin \left(P k_{m} B\right) \sinh \left(Q k_{m} B\right)\right.$

$\left.+\sqrt{a c-b^{2}} \cos \left(P k_{m} B\right) \cosh \left(Q k_{m} B\right)\right\}_{\mathrm{b}}$

$A_{51}=\{\xi P\}_{\mathrm{a}}, \quad A_{52}=\{-\varsigma \mathrm{Q}\}_{\mathrm{a}}, \quad A_{55}=\{-\xi P\}_{\mathrm{b}}, \quad A_{56}=\{\varsigma \mathrm{Q}\}_{\mathrm{b}}$

$A_{63}=\{a-b\}_{\mathrm{a}}, \quad A_{64}=\left\{\sqrt{a c-b^{2}}\right\}_{\mathrm{a}}, \quad A_{67}=\{a-b\}_{\mathrm{b}}$,

$A_{68}=\left\{\sqrt{a c-b^{2}}\right\}_{b}, \quad A_{73}=1, \quad A_{77}=-1$

$A_{81}=\{P\}_{\mathrm{a}}, \quad A_{82}=\{-Q\}_{\mathrm{a}}, \quad A_{85}=\{-P\}_{\mathrm{b}}, \quad A_{86}=\{Q\}_{\mathrm{b}}$

ここで， $\{\ldots\}_{\mathrm{i}}(\mathrm{i}=\mathrm{a}, \mathrm{b})$ は $\{\ldots\}$ の中で $\mathrm{i}$ 層の土質パラメ

一タを用いることを表わす。また， $\xi=-a+\sqrt{a c}$ ， $\varsigma=-a-\sqrt{a c}$ である.

式(37)において, $\chi_{i}(i=1,2, \ldots, 8)$ の係数行列の行列を $A_{i j}(i, j=1,2, \ldots, 8)$ と表わす時, 分岐は $\chi_{i}(i=1,2, \ldots, 8)$ の非 自明な解が存在するとき生じるので, 分岐条件式は,

$$
\operatorname{det}\left(A_{i j}\right)=0
$$

となる。

\section{7. 分岐荷重の解析結果および考察}

本論文においては，梅田層粘土の物質パラメータ の值 $v=0.333, \lambda=0.231, \quad \kappa=0.042, e=1.5, \quad M=1.43$ を基準として用い7），非共軸パラメータ $A$ の值に 関しては参考文献 ${ }^{1)}$ の考察にならい $A=0.01$ を基準 として用いる。したがって，A=0.01を基準とする 本論文は，試行的なものであるが，いずれにしても 非共軸項がない共軸モデルでは，実際現象を説明で きない実例が多々あることが分かってきている． 2 層供試体を考えるときには基準の值を層 $\mathrm{a} に$ 用い, 層 $\mathrm{b}$ には層 $\mathrm{a}$ のパラメータのうち膨潤指数 $\kappa ，$ ある いは圧縮指数 $\lambda$ を $0.8,0.9 ， 1.1 ， 1.2$ 倍したもの, または非共軸パラメータ $A$ を $0.75 ， 0.5$ 倍したもの を用いた 2 層供試体を考える。

分岐条件式は各層の分岐荷重 $\eta=q / p^{\prime}$, 分岐時の 供試体寸法比 $B / H$, 変形モード $m$ の陰関数で与えら れるので, 変形モードと非共軸パラメータを与える ことにより，分岐条件式(39)と式(15), (16)から, 供 試体全体としての「分岐荷重」と分岐時の「供試体 寸法比」の関係を得ることができる．ただし，得ら れた関係は各供試体寸法比に対して，最も低い分岐 荷重を採用している。

各層のパラメータを変える前に両層が同一の物質 パラメータの場合に, 特定のパラメータが分岐荷重

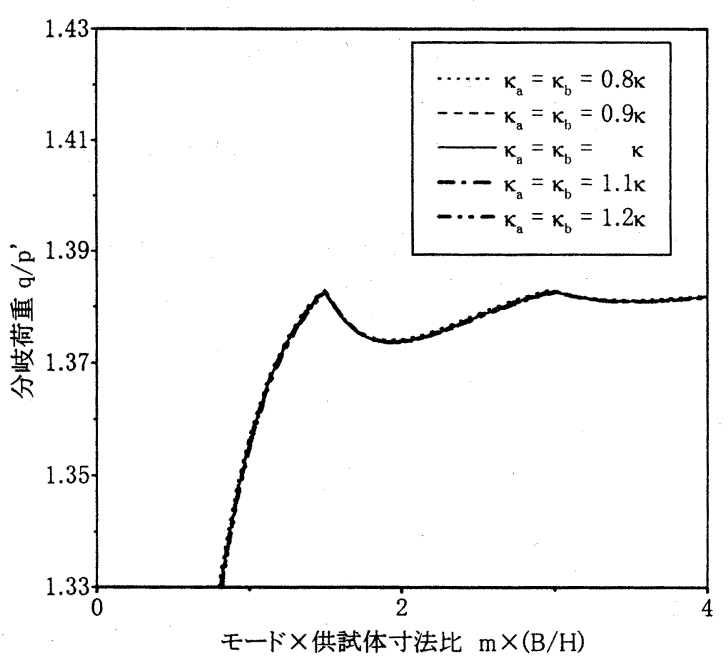

図- 2 膨潤指数 $\kappa$ の変化が分岐荷重とモードおよび 供試体寸法比の関係に与える影響

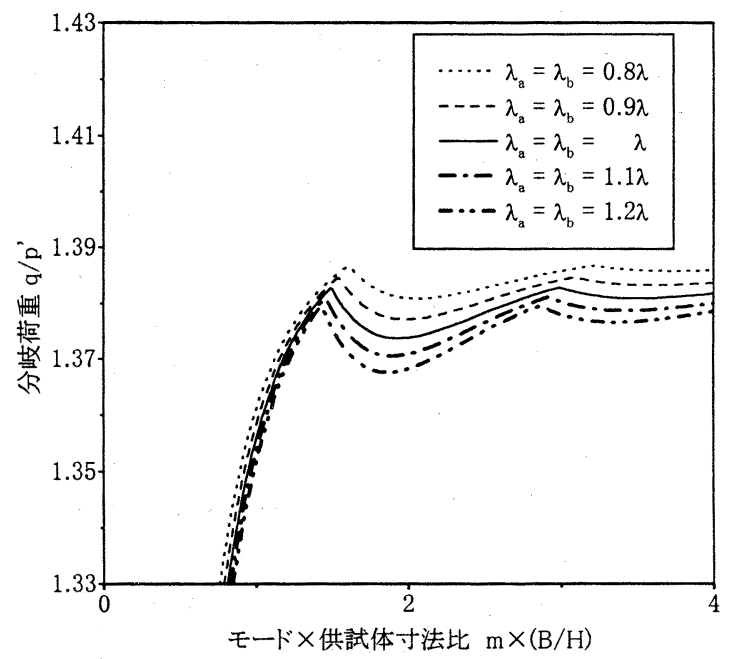

図- 3 圧縮指数 $\lambda$ の変化が分岐荷重とモードおよび 供試体寸法比の関係に与える影響

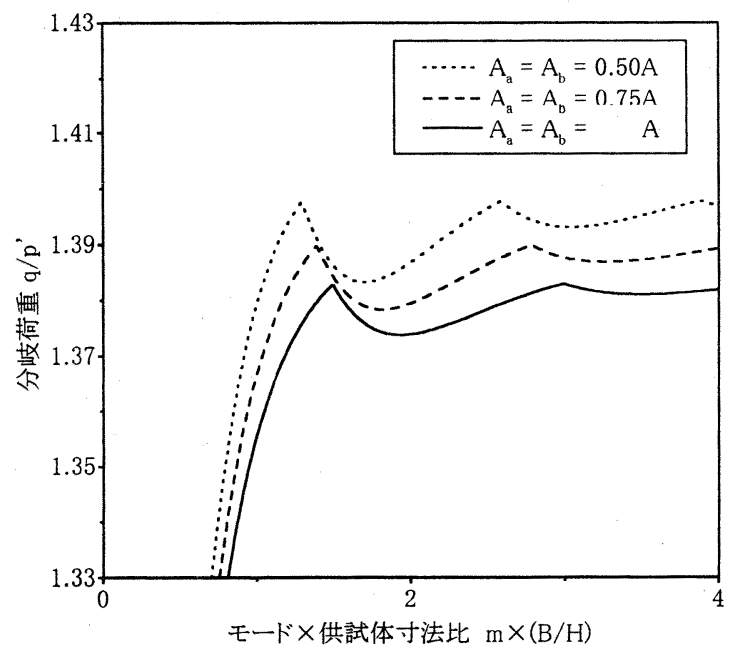

図- 4 非共軸パラメータ $A$ の変化が分岐荷重とモ 一ドおよび供試体寸法比の関係に与える影響 
に与える影響を考察する．図-2 には膨潤指数 $\kappa$ を変 化させた場合, 図-3 には圧縮指数 $\lambda$ を変化させた場 合, 図-4 には非共軸パラメータ $A$ を変化させた場合 の分岐荷重と変形モードおよび供試体寸法比の関係 を示す.

図-2 を見ると膨潤指数 $\kappa$ の変化は分岐荷重にほと んど影響を与えないことがわかる. 図-2 を詳しく調 べると， $\kappa$ が大きくなると分岐荷重は下がる傾向が ある.一方，図-3 を見ると圧縮指数 $\lambda$ の変化は分岐 荷重に大きな影響を与え， $\lambda$ が大きくなると分岐荷 重が下がる傾向がある. 図-4 を見ると非共軸パラメ 一夕 $A$ の変化も分岐荷重に大きな影響を与え, $A$ が大きくなると分岐荷重が下がる傾向がある.

図-5に層 $\mathrm{a}$ と層 $\mathrm{b}$ の膨潤指数 $\kappa$ が異なる場合の分 岐荷重とモードおよび供試体寸法比の関係を示す。 図-2 に示した両層の膨潤指数 $\kappa$ が等しい場合とは異 なり，両層の $\kappa$ が異なる場合は，両層の $\kappa$ 差が大 きいほど分岐荷重が下がる傾向がある，これは，図 -2 において示したように膨潤指数 $\kappa$ が分岐荷重にほ とんど影響を与えないことから，両層の相互干渉の 影響と考えられる.

図-6に層 a と層 b の圧縮指数 $\lambda$ が異なる場合の分 岥荷重とモードおよび供試体寸法比の関係を示す.

図-3に示した両層の圧縮指数 $\lambda$ が等しい場合と同様, $\lambda$ が大きくなると分岐荷重が下がる傾向がある.し たがって膨潤指数 $\kappa$ の場合と異なり，両層の相互干 渉の影響はみられない。

図-7に層 a と層 b の非共軸パラメータ A が異なる 場合の分岐荷重とモードおよび供試体寸法比の関係 を示す. 図-4に示した両層の非共軸パラメータ $A$ が 等しい場合と同様， $A$ が大きくなると分岐荷重が 下がる傾向があり，両層の相互干渉の影響はみられ ない.

\section{8. 最大せん断ひずみ}

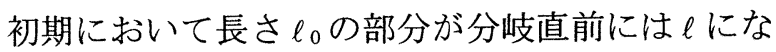

り分岐直後には $\ell+\Delta \ell$ になったとする.

分岐後の主対数ひずみは,

$$
\begin{aligned}
\varepsilon & =\ln \frac{\ell+\Delta \ell}{\ell_{0}} \\
& =\ln \frac{\ell}{\ell_{0}}+\ln \left(1+\frac{\Delta \ell}{\ell}\right)
\end{aligned}
$$

となる. 上式は， $x<1$ なら $\ln (1+x) \approx x$ であるから， $\Delta \ell / \ell \ll 1$ のとき, $\varepsilon$ は次式で近似できるので,

$$
\varepsilon \approx \ln \frac{\ell}{\ell_{0}}+\frac{\Delta \ell}{\ell}
$$

となる. 式(40)より, 分岐直前の一様ひずみ $(\varepsilon)$ と

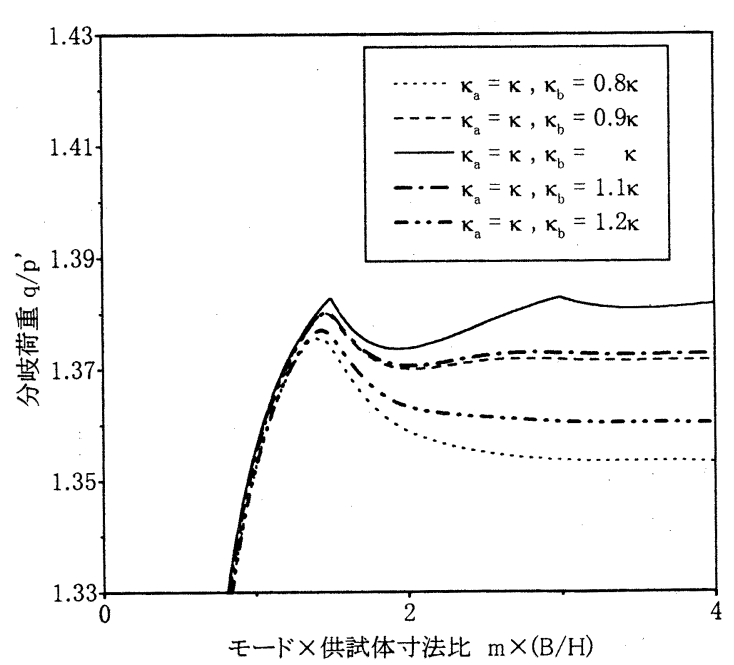

図- 5 分岐荷重とモードおよび供試体寸法比の関係 (層 $\mathrm{a}, \mathrm{b}$ において膨潤指数 $\kappa$ が異なる場合)

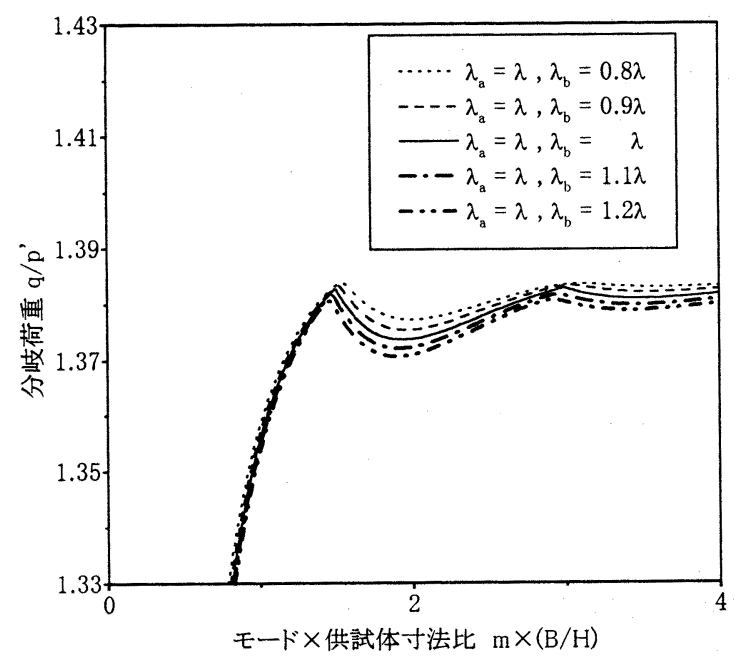

図- 6 分岐荷重とモードおよび供試体寸法比の関係 (層 $\mathrm{a}, \mathrm{b}$ において圧縮指数 $\lambda$ が異なる場合)

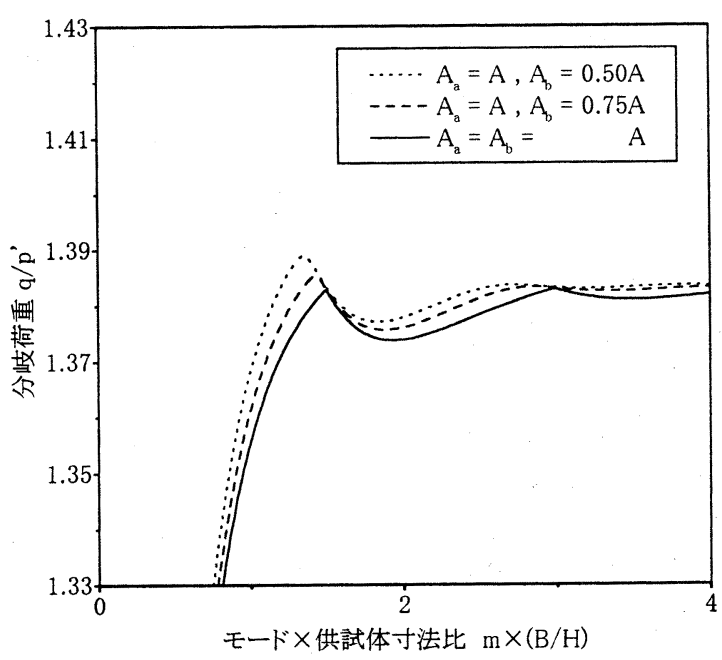

図- 7 分岐荷重とモードおよび供試体寸法比の関係 (層 $\mathrm{a}, \mathrm{b}$ において非共軸パラメータ $A$ が異なる場合) 
変形速度を用いて表すと，

$$
\varepsilon_{i i} \approx\left(\varepsilon_{i i}\right)_{\ell}+D_{i i} \Delta t \quad(i: \text { no sum })
$$

また，分岐直前のせん断ひずみ $\left(\left(\varepsilon_{i j}\right)_{\ell},(i \neq j)\right)$ が零で あることより，

$$
\varepsilon_{i j} \approx D_{i j} \Delta t \quad(i \neq j)
$$

となる。式(41)，式(42)で表わされる $\varepsilon_{i j}$ の主值を $\lambda_{1}, \lambda_{2}, \lambda_{3}\left(\lambda_{1}>\lambda_{2}>\lambda_{3}\right)$ とおき, 最大せん断ひずみ $\Gamma_{\max }$ を次式のように定義する.

$$
\Gamma_{\max }=\frac{\lambda_{1}-\lambda_{3}}{2}
$$

\section{9. 最大せん断ひずみの解析結果および考察}

非共軸 Cam-clay モデルを用いた 2 層供試体の分 岐時の最大せん断ひずみ $\Gamma_{\max }$ の分布を式(43)より求 め, 各変形モードにおけるすべり面（大きなスケー ルでは断層）の発生位置について考察する。通常, 粘土のすべり面は，破壊力学の用語で言えばモード II 型またはモードIII型（せん断型）の進行性破壊で あるので，ここでは，上記の「最大せん断ひずみが 最大となる点がすべり面が最も発生しやすい位置」 と仮定して議論する. 図-8 から図-13 は, 横軸に $x_{1}$ 方向 $\left(-B \leq x_{1} \leq B\right)$, 縦軸に供試体高さ $x_{2}$ 方向 $\left(-H \leq x_{2} \leq H\right)$ をとる. また, 各々の供試体は $H=1$ と した。(a)は分岐時の変形図である。(b)は最大せん 断ひずみ $\Gamma_{\max }$ の分布図で, 色の濃い部分で最大せん 断ひずみが大きく，薄い部分で小さいことを示して いる. なお変形図は分岐時の非均一解による変形の みを表しており，実際の変形図は，すべての領域で 負荷となる自明な均一解の変形を非均一解に加える 必要がある。

図-8,9 では，各層の膨潤指数 $\kappa$ を変化させた場合

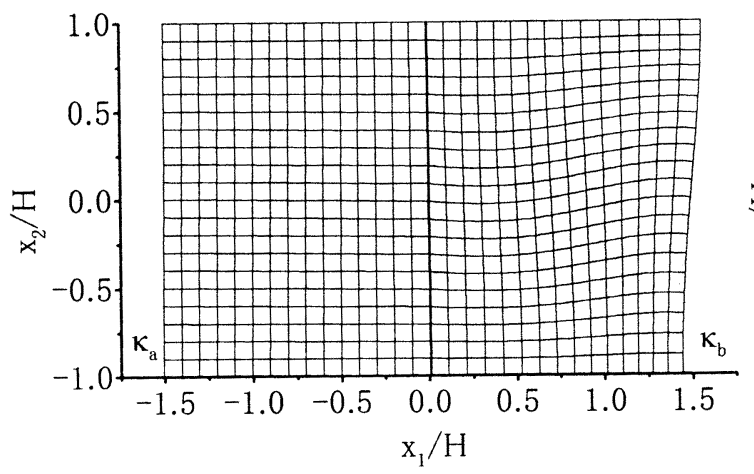

(a)
を，図-10,11 では圧縮指数 $\lambda$ を変化させた場合を， 図-12,13 では非共軸パラメータ $A$ を変化させた場合 を示している。

図-8 は $\kappa_{\mathrm{a}}=\kappa, \kappa_{\mathrm{b}}=0.8 \kappa, m=1, B / H=0.5$ の場合であ る。なお，分岐時には各層の $45^{\circ}$ せん断剛性は $\mu_{\mathrm{a}}^{*} \approx 2.682, \mu_{\mathrm{b}}^{*} \approx 1.329$ となり, 単純せん断剛性は $\mu_{\mathrm{a}} \approx 6.312, \quad \mu_{\mathrm{b}} \approx 4.118$ となっている. 変形モード概 形は図-8(a)に示すように各層の変形は同じ挙動をと っており差違は見られない。図-8(b)からわかるよう に，最大せん断ひずみ $\Gamma_{\max }$ が最大となる位置は膨潤 指数 $\kappa$ が小さい層 $\mathrm{b}$ の表面右下端近傍となっている ことがわかる.このことから，すべり面は表面右下 端近傍から発生しやすいものと考えられる。

図-9 は $\kappa_{\mathrm{a}}=\kappa, \kappa_{\mathrm{b}}=0.8 \kappa, m=1, B / H=1.5$ の場合であ る。なお，分岐時には各層の $45^{\circ}$ せん断剛性は $\mu_{\mathrm{a}}^{*} \approx 0.603, \mu_{\mathrm{b}}^{*} \approx 0.217$ となり, 単純せん断剛性は $\mu_{\mathrm{a}} \approx 2.350, \quad \mu_{\mathrm{b}} \approx 1.028$ となっている. 変形モード概 形は図-9(a)に示すように膨潤指数 $\kappa$ が大きい層 a で

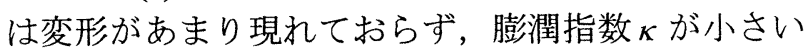
層 b で大きな変形が生じている. 図-9(b)より, 図-8(b) と同様に最大せん断ひずみ $\Gamma_{\max }$ が最大となる位置は 膨潤指数 $\kappa$ が小さい層 b の表面右下端近傍であるこ とがわかる，このことから，すべり面は表面右下端

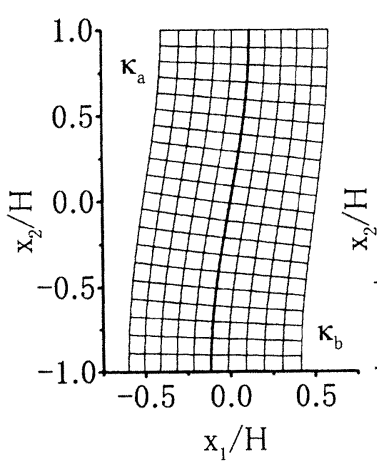

(a)

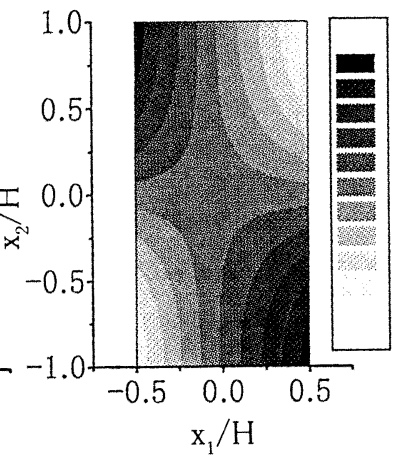

(b)
図- 8 分岐時変形概形および最大せん断ひずみ図 $\kappa_{\mathrm{a}}=\kappa, \kappa_{\mathrm{b}}=0.8 \kappa, m=1, B / H=0.5$

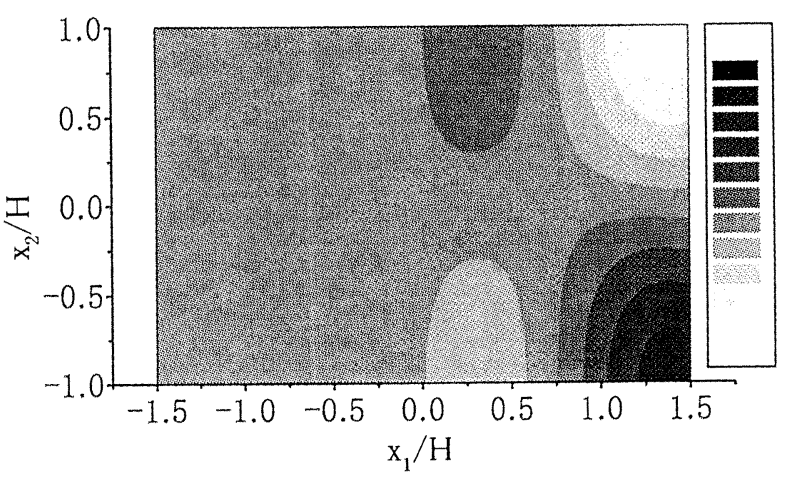

(b)

図-9 分岐時変形概形および最大せん断ひずみ図 $\kappa_{\mathrm{a}}=\kappa, \kappa_{\mathrm{b}}=0.8 \kappa, m=1, B / H=1.5$ 
近傍から発生しやすいものと考えられる.

応力比 $\eta$ が等しいとき, 膨潤指数 $\kappa$ が小さくなる と, 式(14)で与えられる $45^{\circ}$ 世ん断剛性 $\mu^{*}$ は大きく なるので，一定のひずみに対して応力が大きくなる. ゆえに膨潤指数 $\kappa$ が小さい層 $\mathrm{b}$ が早く分岐荷重に達 すると考えられる.

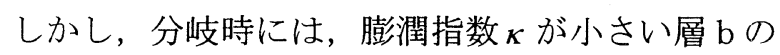

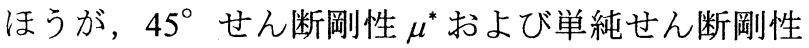
$\mu$ が小さくなっているので分岐を促進し，分岐が生 じた際, 変形が大きくなると考えられる.

図-10 は $\lambda_{\mathrm{a}}=\lambda, \lambda_{\mathrm{b}}=0.8 \lambda, m=1, B / H=0.5$ の場合で ある. なお，分岐時には各層の $45^{\circ}$ せん断剛性は $\mu_{\mathrm{a}}^{*} \approx 1.867, \mu_{\mathrm{b}}^{*} \approx 2.029$ となり, 単純せん断剛性は $\mu_{\mathrm{a}} \approx 5.111, \quad \mu_{\mathrm{b}} \approx 4.844$ となっている. 変形モード概 形は図-10(a)に示すように各層の変形に同じ挙動を とっており差違は見られない. 図-10(b)を詳しくみ ると, 最大せん断ひずみ $\Gamma_{\max }$ が最大となる位置は圧 縮指数 $\lambda$ が大きい層 $\mathrm{a}$ の表面左上端近傍となってい ることがわかる．このことから，すべり面は表面左 上端近傍から発生しやすいものと考えられる。

図-11 は $\lambda_{a}=\lambda, \lambda_{b}=0.8 \lambda, m=1, B / H=1.5$ の場合で ある. なお，分岐時には各層の $45^{\circ}$ せん断剛性は $\mu_{\mathrm{a}}^{*} \approx 0.359, \quad \mu_{\mathrm{b}}^{*} \approx 0.391$ となり, 単純せん断剛性は $\mu_{\mathrm{a}} \approx 1.550, \quad \mu_{\mathrm{b}} \approx 1.354$ となっている. 変形モード概 形は図-11(a)に示すように圧縮指数 $\lambda$ が大きい層 $\mathrm{a}$ では，変形はそれほど大きくないが膨潤指数 $\kappa$ を変 えた場合に比べると変形は大きい. 圧縮指数 $\lambda$ が小 さい層 b では大きな変形が生じている. 図-11(b)よ り, 図-10(b) と異なり最大せん断ひずみ $\Gamma_{\max }$ が最大 となる位置は圧縮指数 $\lambda$ が小さい層 $\mathrm{b}$ の表面右下端 近傍であることがわかる，このことから，すべり面 は表面右下端近傍から発生しやすいものと考えられ る.

応力比 $\eta$ が等しいとき, 圧縮指数 $\lambda$ が小さくなる と, 式(14)で与えられる $45^{\circ}$ 世ん断剛性 $\mu^{*}$ は大きく なるので，一定のひずみに対して応力が大きくなる.
ゆえに圧縮指数 $\lambda$ が小さい層 $\mathrm{b}$ が早く分岐荷重に達 すると考えられる.

分岐時においても，圧縮指数 $\lambda$ が小さい層 $\mathrm{b} の$ $45^{\circ}$ せん断剛性 $\mu^{*}$ は大きい。一方, 単純せん断剛 性 $\mu$ は小さくなっているので, 分岐が生じた際, 変 形が大きくなると考えられる. $B / H=0.5$ の場合は 層幅が薄かったため, 層 $\mathrm{b}$ が分岐した際, 単純せん 断剛性の大きい層 $\mathrm{a}$ に拘束され十分に変形できなか ったものと考えられる. $B / H=1.5$ の場合は, 層 $\mathrm{b} の$

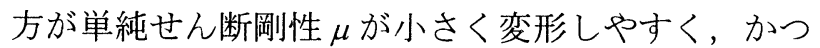
層 $\mathrm{b}$ の最大せん断ひずみの卓越する点が変形を支配 寸る層 a から離れているため, 変形が拘束されず十 分変形できたためであると考えられる.

図-12 は $A_{\mathrm{a}}=A, A_{\mathrm{b}}=0.5 A, m=1, B / H=0.5$ の場合で ある.なお，分岐時には各層の $45^{\circ}$ せん断剛性は $\mu_{\mathrm{a}}^{*} \approx 1.782, \quad \mu_{\mathrm{b}}^{*} \approx 1.782$ となり, 単純せん断剛性は $\mu_{\mathrm{a}} \approx 4.966, \quad \mu_{\mathrm{b}} \approx 8.124$ となっている. 変形モード概 形は図-12(a)に示すように各層の変形は同じ挙動を とっており差違は見られない。図-12(b)を詳しくみ ると, 最大せん断ひずみ $\Gamma_{\max }$ が最大となる位置は非 共軸パラメータ $A$ が小さい層 $\mathrm{b}$ の表面右下端近傍と なっていることがわかる，このことから，す心゙り面

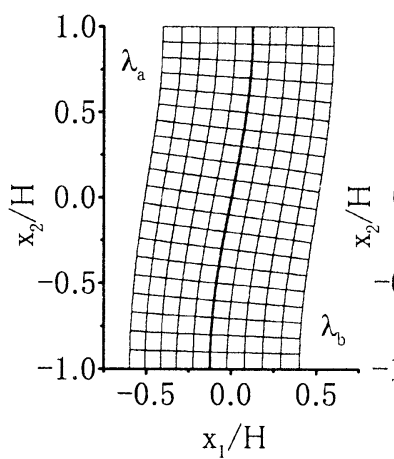

(a)

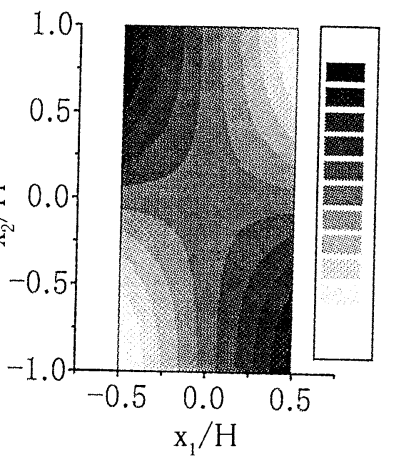

(b)
図-10 分岐時変形概形および最大せん断ひずみ図 $\lambda_{\mathrm{a}}=\lambda, \lambda_{\mathrm{b}}=0.8 \lambda, m=1, B / H=0.5$

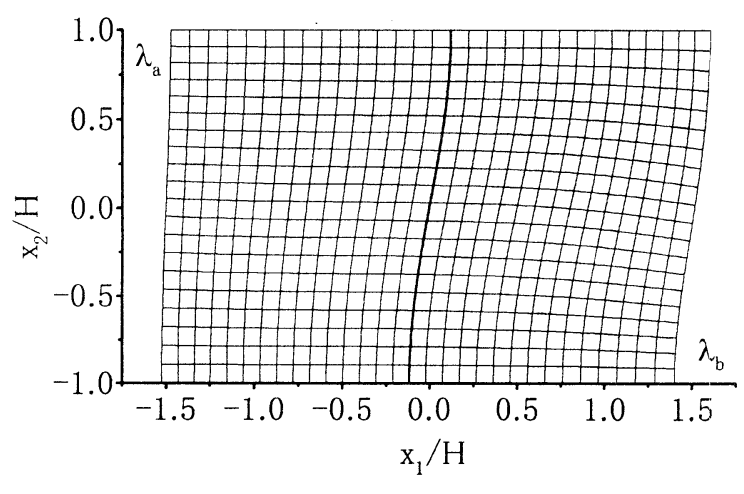

(a)

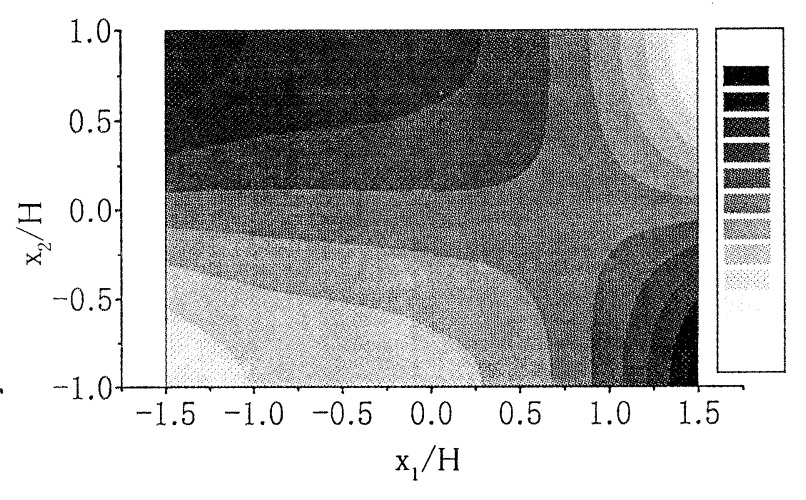

(b)

図- 11 分岐時変形概形および最大せん断ひずみ図 $\lambda_{\mathrm{a}}=\lambda, \lambda_{\mathrm{b}}=0.8 \lambda, m=1, B / H=1.5$ 
は表面右下端近傍から発生しやすいものと考えられ る.

図-13 は $A_{\mathrm{a}}=A, A_{\mathrm{b}}=0.5 A, m=1, B / H=1.5$ の場合で ある.なお, 分岐時には各層の $45^{\circ}$ せん断剛性は $\mu_{\mathrm{a}}^{*} \approx 0.334, \mu_{\mathrm{b}}^{*} \approx 0.334$ となり, 単純せん断剛性は $\mu_{\mathrm{a}} \approx 1.459, \quad \mu_{\mathrm{b}} \approx 2.739$ となっている. 変形モード概 形は図-13(a)に示すように両層とも下端が膨らむ挙 動をとっている。図-13(b)より，最大せん断ひずみ $\Gamma_{\max }$ が最大となる位置は供試体中央部下部であり, 詳しく調べると非共軸パラメータ A が小さい層 b の 側であることがわかる。このことから，すべり面は 中央下端近傍から発生しやすいものと考えられる.

非共軸パラメータ $A$ は，式(14)の $45^{\circ}$ せん断剛性 $\mu^{*}$ には影響を与えないが，Aが小さくなると単純 せん断剛性 $\mu$ は大きくなる。

分岐時においても，両層で $\mu^{*}$ は等しく，非共軸 パラメータ $A$ の小さい層bのほうが $\mu$ は大きい，図 $-12,13$ どちらの場合も層 a の方が変形しやすいが最 大せん断ひずみの卓越する点が変形を支配する層 $\mathrm{b}$ の影響を受けているため層 b の側に最大せん断ひず みの最大の位置が現われたものと考えられる.

以上は，はじめに述べたように，すべり面は，仮 に初期に「拡散分岐モード (Diffuse bifurcation mode）」の出現した場合, 速度勾配により定義した 「最大せん断ひずみ」の概念を使って，初期すべり面 の発生源となる可能性の高い位置を考察したもので ある。

なお，すべり面発生の考察として，双曲型または 放物型における速度勾配の不連続面で定義される

「せん断帯モード（Shear band mode）」発生の必要 条件に基づいた議論も，数多く行なわれているが, その条件では，せん断帯モードとしてのすべり面の 発生する応力状態やその方向は議論できるが，境界 条件に無関係な局所的な理論であるため，本分岐解 のように，特定の供試体形状におけるすべり面の発 生位置までは議論できない.

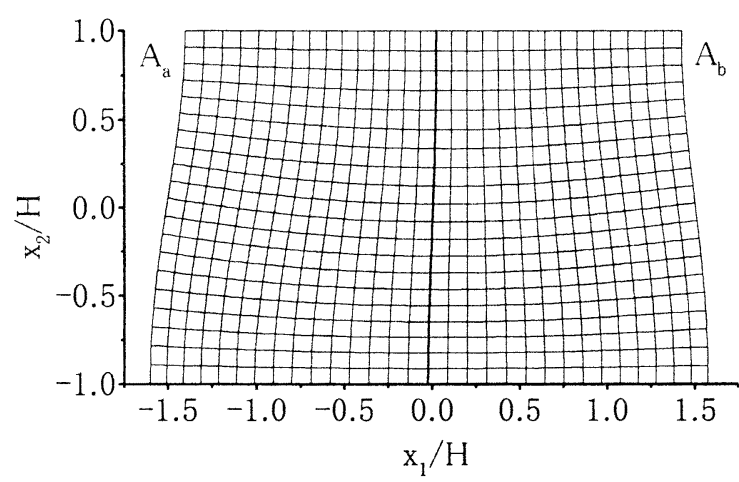

(a)

\section{0.おわりに}

本論文では，有限変形非共軸 Cam-clay モデルを 用いた 2 層供試体の分岐解析を行うことにより，ま ず, 分岐条件式を求め, 分岐荷重と変形モードとの 関係を議論した. 次に最大せん断ひずみの分布を求 めることにより, すべり面の発生位置について考察

した. 本論文で得られた結論を以下に列記する。

（1） 2 層供試体の分岐荷重の理論解を得た.

（2） 2 層の圧縮指数 $\lambda$ あるいは非共軸パラメータ $A$ の相違は分岐荷重に大きな影響を与えない.

（3） 2 層の膨潤指数 $\kappa$ の相違は分岐荷重に大きな 影響を与え，2 層の膨潤指数の差が大きいほ ど分岐荷重は下がる傾向にある.

（4）いくつかの 2 層供試体の変形モードに対して 最大せん断ひずみの分布を求め, 初期すべり 面の発生し易い位置を求めた.

なお，本論文では，高次の変形モードは紙面の都合 上, 割愛した。

\section{Appendix}

分岐の瞬間までは, 均一状態を保つから，式(2)よ り, $x_{2}$ 方向の平均の有効応力は, 各層の層幅が $B_{\mathrm{a}}$, $B_{\mathrm{b}}$ とすると

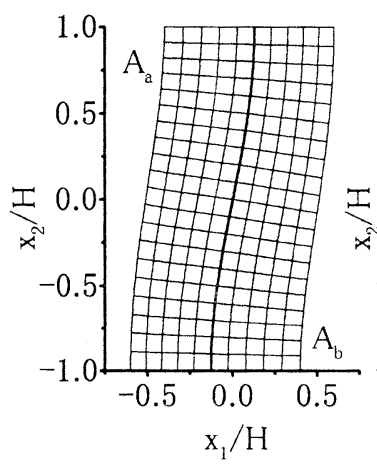

(a)

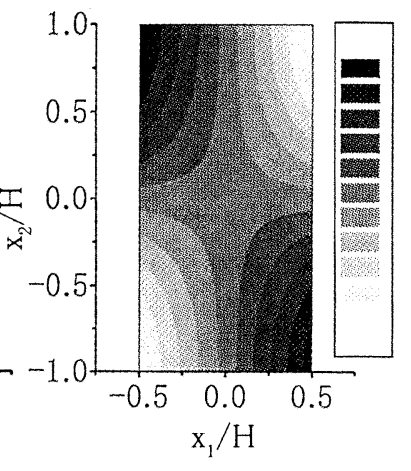

(b)
図-12 分岐時変形概形および最大せん断ひずみ図 $A_{\mathrm{a}}=A, A_{\mathrm{b}}=0.5 A, m=1, B / H=0.5$

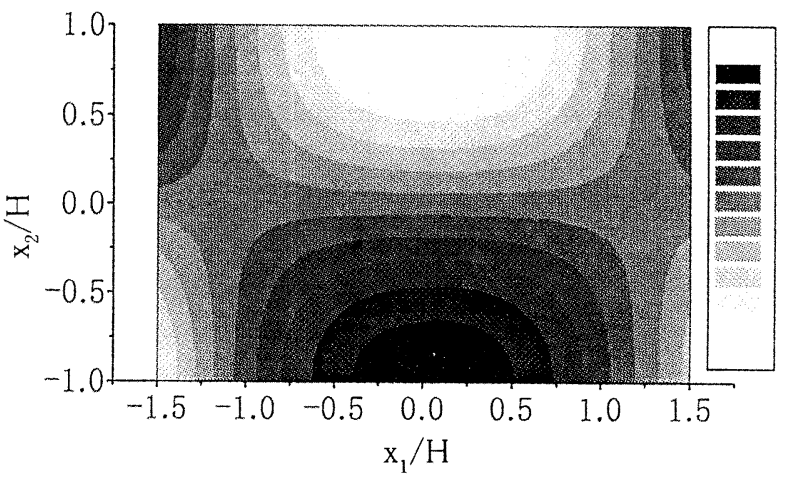

(b)

図- 13 分岐時変形概形および最大せん断ひずみ図 $A_{\mathrm{a}}=A, A_{\mathrm{b}}=0.5 A, m=1, B / H=1.5$ 


$$
\sigma_{2}^{\prime}=\frac{B_{\mathrm{a}} \sigma_{\mathrm{a}_{2}}^{\prime}+B_{\mathrm{b}} \sigma_{\mathrm{b}_{2}}^{\prime}}{B_{\mathrm{a}}+B_{\mathrm{b}}}
$$

となる. 一方, 間隙水圧が両層で等しい場合は， $x_{1}$ 向の有効応力は,

$$
\sigma_{1}^{\prime}=\sigma_{\mathrm{a}_{1}}^{\prime}=\sigma_{\mathrm{b}_{1}}^{\prime}
$$

となる. よって 2 層体としての平均有効主応力 $p^{\prime}$ と一般化された偏差応力 $q$ は次式のようになる.

$$
\begin{aligned}
p^{\prime} & =\frac{\sigma_{1}^{\prime}+\sigma_{2}^{\prime}}{2}=\frac{B_{\mathrm{a}} \sigma_{\mathrm{a} 2}^{\prime}+B_{\mathrm{b}} \sigma_{\mathrm{b} 2}^{\prime}+\left(B_{\mathrm{a}}+B_{\mathrm{b}}\right) \sigma_{1}^{\prime}}{2\left(B_{\mathrm{a}}+B_{\mathrm{b}}\right)} \\
& =\frac{\sigma_{\mathrm{a} 2}^{\prime}+\sigma_{1}^{\prime}}{2} \frac{B_{\mathrm{a}}}{B_{\mathrm{a}}+B_{\mathrm{b}}}+\frac{\sigma_{\mathrm{b} 2}^{\prime}+\sigma_{1}^{\prime}}{2} \frac{B_{\mathrm{b}}}{B_{\mathrm{a}}+B_{\mathrm{b}}} \\
& =p_{\mathrm{a}}^{\prime} \frac{B_{\mathrm{a}}}{B_{\mathrm{a}}+B_{\mathrm{b}}}+p_{\mathrm{b}}^{\prime} \frac{B_{\mathrm{b}}}{B_{\mathrm{a}}+B_{\mathrm{b}}} \\
q & =\frac{\sqrt{3}}{2}\left|\sigma_{2}^{\prime}-\sigma_{1}^{\prime}\right|=\frac{\sqrt{3}}{2}\left|\frac{B_{\mathrm{a}} \sigma_{\mathrm{a}}^{\prime}+B_{\mathrm{b}} \sigma_{\mathrm{b} 2}^{\prime}-\left(B_{\mathrm{a}}+B_{\mathrm{b}}\right) \sigma_{1}^{\prime}}{B_{\mathrm{a}}+B_{\mathrm{b}}}\right| \\
& =\frac{\sqrt{3}}{2}\left|\left(\sigma_{\mathrm{a} 2}^{\prime}-\sigma_{1}^{\prime}\right) \frac{B_{\mathrm{a}}}{B_{\mathrm{a}}+B_{\mathrm{b}}}+\left(\sigma_{\mathrm{b}}^{\prime}-\sigma_{1}^{\prime}\right) \frac{B_{\mathrm{b}}}{B_{\mathrm{a}}+B_{\mathrm{b}}}\right| \\
& =q_{\mathrm{a}} \frac{B_{\mathrm{a}}}{B_{\mathrm{a}}+B_{\mathrm{b}}}+q_{\mathrm{b}} \frac{B_{\mathrm{b}}}{B_{\mathrm{a}}+B_{\mathrm{b}}}
\end{aligned}
$$

ゆえに2 層系全体としての場合の分岐荷重は,

$$
\frac{q}{p^{\prime}}=\frac{B_{\mathrm{a}} q_{\mathrm{a}}+B_{\mathrm{b}} q_{\mathrm{b}}}{B_{\mathrm{a}} p_{\mathrm{a}}^{\prime}+B_{\mathrm{b}} p_{\mathrm{b}}^{\prime}}
$$

となり，層幅の等しい場合は,

$$
\frac{q}{p^{\prime}}=\frac{q_{\mathrm{a}}+q_{\mathrm{b}}}{p_{\mathrm{a}}^{\prime}+p_{\mathrm{b}}^{\prime}} \quad(16: \text { 再掲 })
$$

となる.ゆえに，両層分岐時の間隙水圧が等しい場 合の層幅の等しい 2 層供試体の分岐荷重は式(16)で 定義できる．２層供試体の分岐荷重には様々な定義 が考えられるが上記のような例もあるので，本論文 では，式(16)を分岐荷重として定義する.

\section{参考文献}

1) Biot, M. A. : Mechanics of the Incremental Deformation, Wiley, New York, 1965.

2) Yatomi, C., Yashima, A., Iizuka, A., and Sano, I. : General theory of shear bands formation by a noncoaxial Cam-clay model, Soils and foundations, Vol.29, No.3, pp.41-53, 1989.

3) Roscoe, K. H., Schofield, A. N. and Thurairajah, A : Yielding of clays in states wetter than critical, Geotechnique, Vol. 13, pp. 211-240, 1963.

4) Ohta, H. : Analysis of deformations of soils based on the theory of plasticity and its application to settlement of embankments, Doctor Engineering Thesis, Kyoto Univ., 1971.

5) 例えば, 志比利秀, 矢富盟祥: 有限変形非共軸 Cam-clay モデルによる中空円柱供試体の非軸対 称分岐解析, 応用力学論文集, Vol.1, pp. 537-546, 1998.

6) 伊藤耿一：塑性不安定と分岐の理論, 塑性と加 工, Vol.22-249, pp. 1009-1015, 1981.

7) Sekiguchi, H. : Rheological characteristics of clays, Proc. 9th ICSFME, Tokyo, Vol.1, pp.289-291, 1977.

（1999 年 4 月 23 日受付） 